EREM 77/4

Journal of Environmental Research, Engineering and Management

Vol. 77 / No. 4 / 2021

pp. 48-63

DOI 10.5755/j01.erem.77.4.29163
An Innovative Approach to the Implementation of Sustainable Business Ideology in Ukraine
Accepted after revision 2021/11

\title{
An Innovative Approach to the Implementation of Sustainable Business Ideology in Ukraine
}

\author{
Borys Burkynskyi, Natalya Andryeyeva, \\ Nina Khumarova, Kateryna Kostetska* \\ Institute of Market Problems and Economic-Ecological Research NAS of Ukraine, 65044, Odessa, \\ Francuzskiy bylvar, 29, Ukraine
}

*Corresponding author: kathryn81@ukr.net

According to the Sustainable Development Goals (UN, 2015), making sustainable business decisions should be the driving force in achieving environmentally-oriented improvements. The key document that supports the 10 principles that ensure SDGs is the United Nations Global Compact Strategy 2021-2023 (UN, 2021). Achieving the goals of the Strategy requires the use of an improved business decision-making model that simultaneously increases revenues and revises the distribution of domestic funds for meeting the principles in the sphere of human rights, economic growth, satisfactory working conditions and the environment, and combating corruption as a key driver of corporate sustainability and responsible business practices. The authors have developed a methodological approach to the assessment of business sustainability, which is based on a combination of elements: analysis of world best practices and trends, determination of the impact of business on the social status and environment, quality assessment of relevant certification, and analysis of compliance with social indexes of sustainable development. The analysis of economic indicators of sustainable business (The B Impact Assessment, 2021) for 2020-2021 allowed singling out companies that finance the environmental sphere. Today, a quarter of the world's countries carry on sustainable business and finance the environmental degradation impact. The 8 leaders include: France, USA, Brazil, India, Germany, Norway, Ireland and South Korea. Methods of rating and expert assessment constitute an applied aspect of research for identification of prospects of sustainable business formation in Ukraine in the regional context. The result shows that only 8 regions are suitable for sustainable business conduct, while the environmental criterion is more than 9.2 points of 10 , the 
economic criterion does not exceed 5, and the social criterion is 4.02-5.02. Therefore, it is necessary to focus on the organization of sustainable business according to the key strategic state priorities in formation of the mechanisms for the investment and the innovation policy of a sustainable development support system through the use of regulatory tools for reformation of existing business approaches to internationally regulated ones, such as business for nature.

Keywords: sustainable business, business for nature, Sustainable Development Goals, social, economic, environmental criterion

\section{Introduction}

Today's crisis phenomena, caused by the increasing stress on the environment, have led to deterioration in the quality of life and health of the nation and, as a result, to an economic downturn. The United Nations Report: Nature's Dangerous Decline 'Unprecedented; Species Extinction Rates 'Accelerating' regarding the dangerous state of nature notes that business organizations in economically developed countries allocate funds for environmental protection with increasing frequency (UN, 2021). Such activities are spelled out in one of the world's main documents: "Transforming our World: the 2030 Agenda for Sustainable Development" (UN, 2015). The UN Global Compact Strategy 2021-2023 (UN, 2021) report emphasizes that the sustainable development of the country's business and economy depends on environmental services provided for the free use of the natural environment. International economists (Mcusik, 2020; Costanza et al., 2017; Groot et al., 2012) have estimated the cost of such services to amount to 70-125 trillion US dollars. World practice shows that the most successful business is conducted on a mutually beneficial relationship with nature.

According to the Sustainable Development Goals 2030 (UN, 2015), the driving force in achieving environmentally-oriented improvements should be the adoption of sustainable business decisions. The UN Global Compact Strategy for 2021-2023 (UN, 2021) highlights the directions for acceleration and scaling up of the global collective impact of business, focusing on supporting the 10 principles that ensure SDGs. Achieving the goals of the Strategy requires the use of an improved business decision-making model that simultaneously increases revenues and revises the distribution of domestic funds for meeting the principles in the sphere of human rights, economic growth, satisfactory working conditions and the environment, and combatting corruption as a key driver of corporate sustainability and responsible business practices.

Research of the Business for Nature (Duckett, 2020) has proved that more than half of the global GDP, which amounts to 44 trillion US dollars of economic value, faces moderate or serious risks due to the nature loss. Thus, as of April 2021, according to the data of the Global Compact Strategy for 2021-2023 (UN, 2021), more than 530 companies worldwide actively participate in the prevention of the environmental degradation impact; 1240 companies focus their business activities on reducing the environmental impact; 700 companies, working with the government, focus on environmental policy; and more than 200 companies work with Business for Nature for the development of 5 recommendations with regard to the sustainable nature management and work with the government for adoption of policies aimed at the reduction of nature loss this decade.

One of the common tools in foreign countries for improvement of their business impact on the environment is Certified B Corporations (B-Corp certification), which meets certain standards of social and environmental indicators, public transparency and legal accountability. Today, parameters for assessment of the impact of business on various environmental and social spheres have been developed. Open data (The B Impact Assessment, 2021) confirm that there are 900 certified B-Corp companies and 15000 companies in the world that have joined the policy of introducing B-Corp business. These strategic documents, action 
programs and implementation tools prove the need to study international practices and experiences in order to spread their influence into the Ukrainian plane.

The aim of the research is a scientific generalization of international approaches to sustainable business conduct and the definition of regional development criteria for calculation of socio-economic and environmental feasibility of implementing the practices in Ukraine.

\section{Materials and methods}

In order to determine the theoretical and applied basis of the article, the authors used the following methods: the method of scientific abstraction, as one of the most important tools for theoretical generalization; the method of scientific research for separation of the necessary properties and signs of sustainable development in business without taking into account the nonessential properties and insignificant aspects of the process; the method of generalization for determination of the main guidelines for sustainable business development in accordance with international practices and recommendations.

The methodological basis of research is the authors' scientific approach to assessing the integration of business into sustainable development based on a combination of elements: analysis of the best world practices and trends, determination of the impact of business on the social state and environment, assessment of the quality of the relevant certification, as well as analysis of compliance with social and environmental standards (indexes) of sustainable development. The authors also used the Delphi technique for scientific and technical forecasting according to ecological, economic and social criteria of the development of regions of Ukraine. This meets the standard ISO 31010 - Risk Management. Risk assessment techniques (ISO, 2009). The main features of the Delphi technique are anonymity, multilevel process and correspondence. The idea of the method is that if one properly generalizes and processes the individual assessments of experts about a particular situation, a general opinion that will have the maximum degree of reliability may be formed (Harold \& Murray, 1975). The point of the method is to find a way to determine the right decision with the help of a set of certain actions, such as brainstorming, interviews and polls. The method is based on the fact that a certain group of independent experts is much better able to evaluate and predict the result than a structured group of people. Taking into account the fact that independent experts may not even know about each other, it is possible to exclude the clash of different positions, as well as the collective influence due to joint work and conformism. The method can be carried out anywhere, regardless of the location of the participants. Its implementation was based on the opinions of experts for building a future model of sustainable business development. The experts were 2 professors and 2 PhDs of the Department of Economic Regulation of Environmental Management, 2 professors of the Department of Economic and Environmental Problems of Coastal Regions of the Institute of Market Problems and Economic Ecological Research of the National Academy of Sciences of Ukraine and 2 professors of the Odessa State Ecological University of the Ministry of Education of Ukraine. The key information of the research is a review of opinions of world scientists and specialists in the field of management, regional development, economics of nature management, and ecological innovations. The rating method was used by the scientists for numeric expression of the importance of criteria and the closeness of the relationship between social, economic and environmental criteria regarding the prospects of sustainable business formation in Ukraine. The regions for the study were selected on the basis of their attractive natural resource potential as those that represent the potential for investment activities. According to the State Statistical Service of Ukraine (SSSU, 2021), the capital investments amount to 2962.3 thousand US dollars for Odessa region; 3445.8 thousand US dollars for Kiev region; and 2243.1 thousand US dollars for Lviv region. Also, by gross regional product (SSSU, 2021), the regions are as follows: Zaporozhye region with 56500.0 thousand US dollars; Kiev region with 440111.11 thousand US dollars; Lviv region with 518222.12 thousand US dollars; Odessa region with 630703.34 thousand US dollars; and Kharkov region with 760148.44 thousand US 
dollars). Personnel costs of enterprises (Personnel costs of enterprises, 2021) amount to 3985.82 million US dollars in Dnipropetrovsk region; 2045.48 million US dollars in Kiev region; 1676.94 million US dollars in Lviv region; 1372.92 million US dollars in Odessa region; 1784.64 million US dollars in Kharkov region. The number of employees of business entities (Number of employees of business entities, 2021) is as follows: 306 thousand in Zaporozhye region; 369 thousand in Kiev region; 470 thousand in Lviv region; 346 thousand in Odessa region; 448 thousand in Kharkov region. The distribution of regions according to the selected criteria was carried out by the method of ranking based on the rationing of individual indicators.

\section{Results and Discussion}

The institutional basis for business in combination with the Sustainable Development Goals covers the UN Global Compact Strategy 2021-2023 (UN, 2021), Purpose: Good business and a better future (Deloitte, 2017), OECD (Organization for Economic Co-operation and Development) Guidelines for Responsible Business (OECD, 2011), and the Concept for implementation of state policy in the field of promoting the development of socially responsible business in Ukraine for the period up to 2030 as an action plan of Verkhovna Rada of Ukraine (VRU, 2020) for Business for Nature.

The conduct of business following the principles of sustainable development provides investment benefits, such as low-interest lending, public support, which attract foreign investors and cooperation with administrative bodies. Today there are several scientific terms that are closely related, but have some differences. These include sustainable business, "green" business, and responsible business. According to the definition of Sweden Sustainable Business (GSB, 2020), sustainable business is an economic activity with profitability, caring for the environment and social obligations in equilibrium (Elkington, 2004).

This defines sustainable business as the practice of business without a negative impact on the environment. According to John Elkington (2004), sustainable business takes into account 3 components of the triple result: profit, people, and planet. Sustainable business is profitable, being socially responsible, and does not deplete the use of the planet's resources. The Green Business Definition: Everything You Need to Know shows that "green" business must meet the following criteria: the mission of the business based on the principles of sustainable development; production or supply of environmentally friendly products and services; obligatory compliance with the requirements and principles of environmental protection (Upcounsel, 2021). Responsible Business (Impact Garden, 2020) emphasizes benefits to society and addresses the negative consequences which it can have on society, people, and planet. Thus, it can be noted that sustainable business includes green business and responsible business. However, sustainable business can not be green, but part of the profit has to be necessarily directed to ecological goals.

The research of world scientists on sustainable business is divided into various approaches to the main dominants of sustainability. Thus, according to researchers (Zahid et al., 2021; Jonkute, 2015; Lassaad \& Khmaoussi, 2012; Raed \& Mohamad, 2020; Geissdoerfer et al., 2018), the integration of sustainability practices in the workplace is one of the top priorities. The authors prove that sustainability in the workplace directly affects the company's financial performance and is a driving force for achieving environmental initiatives, namely the implementation of an environmental management system (EMS) (US EPA, 2021) and the international environmental management standard ISO 14001 (ISO, 2011). In their research, Bansal and DesJardine (2014), Geissdoerfer et al. (2018), Groot et al. (2012) prove that sustainable business takes into account the parameters of time, namely business conduct. It manages intertemporal compromises in making strategic decisions, so that both short-term and long-term perspectives are taken into account.

Research of small business interests in sustainable business conduct (Mikusova, 2017) proves that, under current conditions, interests are focused on shortterm perspectives, and the focus on sustainability is associated with risks, namely with the need for costs associated with the acquisition of assets. Thus, the 
factor of positive influence should be the policy of the state focused on benefits or grants for the purchase of environmentally friendly equipment, free consultations and examinations.

A wide range of scholars (Gómez-Bezares et al., 2016; Rahdari et al., 2016; Jonkute, 2015; Stasiskiene, 2021) view sustainable business through the lens of social and cultural processes inherent in the horizontal integration of value-driven functions as the main guidelines for applying innovation in their activities to achieve environmentally friendly production and consumption.

Summarizing the main ideas of the research, the authors propose a methodological approach to assessing the integration of business to sustainable development, as shown in Fig. 1.

Sustainable business includes the following blocks:

1 First, this is a measurement of impact assessment focused on the influence of business over the parameters of sustainability. Internationally, there are 3 approaches to measurement:

The guide for business action on the Sustainable Development Goals Compass (SDG Compass, 2015) provided by business management to implement their development strategies for sustainable development;

Communication on Engagement Report (COE, 2021), which contains information about companies that conduct sustainable business, assessment of their impact on sustainability and key performance indicators;

B Impact Assessment (The B Impact Assessment, 2021), which is a free confidential platform designed to measure and manage a company's positive impact on its employees, community, customers and the environment.

2 Certification and rating of business is carried out through surveys:

A Global Community of Leaders (B-Corp, 2021). Obtention of the certificate involves business conduct that provides a balance between sustainable development goals and profit. Operation of companies is fully committed to take into account the impact of its decisions on employees, customers, suppliers, community, and environment.
EU Taxonomy Solution (EU, 2021) is a company where the activities are related to research and ranking of environmental, social and corporate governance of ESG business. Ratings are published on the web-site and can be used by both the company and investors.

An MSCl ESG Rating, analyzed by Morgan Stanley Capital International (MSCl, 2019), conducts business evaluations depending on risks of investment activities and ability to manage them.

An industry-leading innovative approach to ESG risk assessment and due diligence (Label $R, 2018$ ) carries out risk assessment and due diligence, covering environmental, social and corporate governance (ESG) in combination with business ethics, including anti-money laundering, combating corruption and ethical financial practices.

3 Reporting is the business practice of disclosing the impact of its activities on the economic, environmental and social spheres.

4 Standards and indexes. The following are most common in sustainable business:

ISO 26000 - Guidance on Social Responsibility (ASQ, 2019). Social responsibility of ISO 26000 provides guidance on how enterprises and organizations can work in a socially responsible manner. This means to act ethically and transparently, which contributes to the health and well-being of society.

ISO 14000 Family Environmental Management (ISO, 2011). The environmental management standard provides practical tools for companies and organizations of all types which want to manage their environmental functions.

The Global Standard in Measuring and Managing a Company's Social Impact, Business for Societal Impact (B4SI, 2020) is a global standard for measuring and managing a company's social impact.

The Dow Jones Sustainability Index (S\&P Global, 1999) tracks the indicators of inventories of the world's leading companies in terms of economic, environmental and social criteria. The S\&P ESG family of indexes offers investors an impact on companies according to their ESG profile in the context of individual and regional indexes. The in- 
Fig. 1. A methodological approach to assessing the integration of business to sustainable development

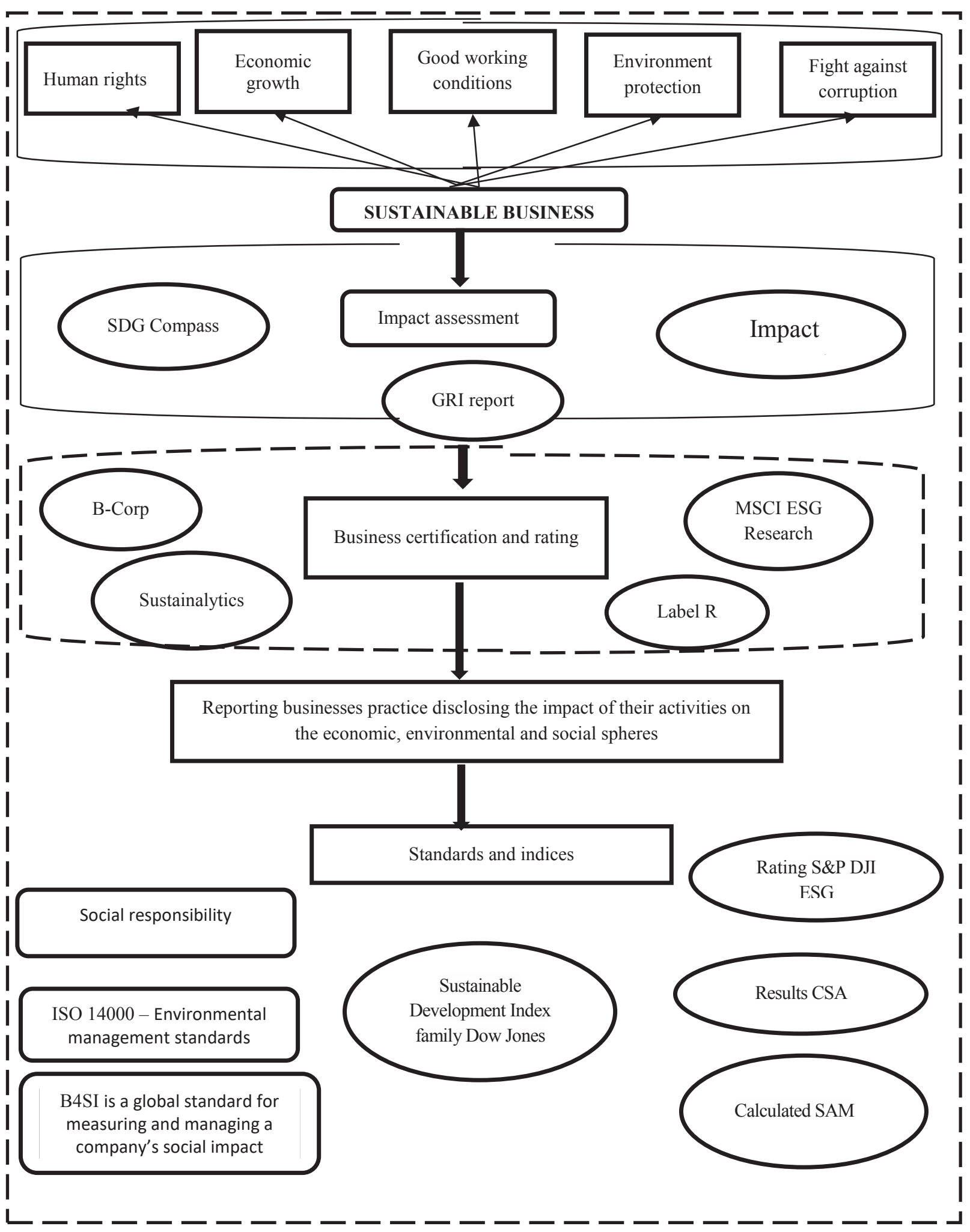


dex family is based on S\&P DJI ESG assessments, on the results of the Canadian Standards Association (CSA, 2013) and is calculated by SAM.

In focusing on innovative approaches to sustainable business, there is a need to transfer international practice to the Ukrainian plane and compare world practices of sustainable business with Ukrainian. In Ukraine, certification is divided into mandatory and voluntary. Business, where activities or products may have a negative impact on the environment, human safety and property, is subject to mandatory certification. Also, along with the standards of environmental management and corporate governance existing in Ukrainian legislation, there are State Standards of Ukraine (DSTU), i.e., standards developed in accordance with the current legislation of Ukraine, establishing general and repeated application of rules, general principles or characteristics relating to the activity or its results, in order to achieve the optimal degree of order, developed by consensus and approved by an authorized body (DSTU, 2018). DSTU regulates the mandatory requirements for product quality and technical specifications (TS) that establish the technical requirements that products, processes or services must meet.

Thus, the focus on sustainable business involves focusing on people and the needs of employees to ensure individual and collective success, innovation in everything, full transparency of activity, concern for customer, exceedance of consumer expectations, commitment and fulfilment of external and internal obligations, and protection of the environment through a circular economy.

In international guidelines, life cycle sustainability assessment (LCSA) includes three stages (LCSA, 2020):

assessment of the company's activity over a period of 3 years;

assessment of the effectiveness of minimizing risks and the ability to resist them;

assessment of country and regional risks according to 3 blocks: environmental impact (rating indicator), social policy (rating indicator), and assessment of the quality of corporate governance (best practice). Each of the blocks has a weight of $33.3 \%$ in the overall ESG assessment. This assessment includes key indicators of sustainable development.
The ecological block includes waste generation, water consumption, hazardous substances emissions, greenhouse gas emissions, energy consumption, and waste-water discharges. The block of social responsibility includes staff turnover, wages, gender composition, injuries, mortality, and social investments. The block of quality management consists of independence, experience in the industry, concentration of corporate ownership, information disclosure, management strategy and management structure and showing the best practice.

Since 2020, Corporate Knights (CK) compiles a rating of sustainable business, which includes 100 positions using this methodology (CK, 2021). The general rating of the countries upon all indicators of sustainable business has the following form presented in Fig. 2, where the best indicator is the lowest rating.

Analysis of economic indicators of sustainable business (CK, 2021) for 2020-2021 under the environmental block allowed us to single out areas of their activities by the number of companies and financing into the environmental sphere by energy productivity, carbon productivity, water productivity, and waste productivity (Table 1).

The comparison shows that almost a quarter of the world's countries unanimously conduct sustainable business and finance the environment degradation impact. The 8 leaders by four environmentally-oriented indicators, i.e., energy productivity, carbon productivity, water productivity, waste productivity, include:

France - 29406113.6 thsd US dollars;

United States - 1608358.01 thsd US dollars;

Brazil - 345241.57 thsd US dollars;

India - 327170.90 thsd US dollars;

Germany - 232243.38 thsd US dollars;

Norway - 227682.01 thsd US dollars;

Ireland - 104490.31 thsd US dollars;

South Korea - 116077.37 thsd US dollars.

At the same time, almost $99 \%$ of investments are allocated to overcoming the effects of waste productivity.

Middle peasants distribute their funding in the following proportions: $75 \%$ for waste productivity, and $22 \%$ for carbon productivity. The most significant contribution is made by Italy with 84029.65 thsd US dollars, 
Fig. 2. Ranking of countries by indicators of sustainable business (calculated by the authors according to CK, 2021)

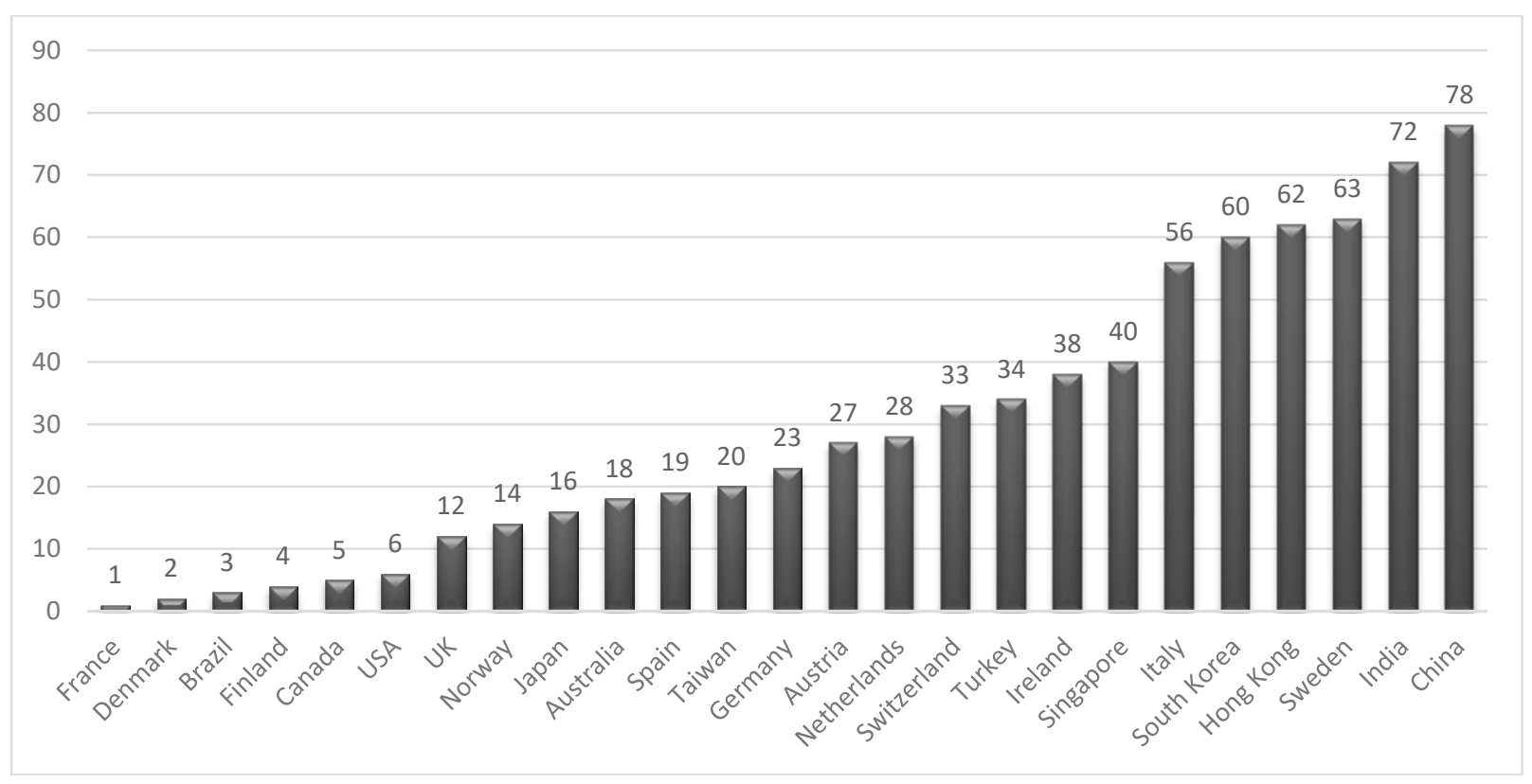

Table 1. Ranking of countries by the environmental block of sustainable business

\begin{tabular}{|c|c|c|c|c|c|c|}
\hline Country & $\begin{array}{l}\text { Number of } \\
\text { companies }\end{array}$ & $\begin{array}{c}\text { Energy } \\
\text { productivity, US } \\
\text { thsd dollars }\end{array}$ & $\begin{array}{c}\text { Carbon } \\
\text { productivity, US } \\
\text { thsd dollars }\end{array}$ & $\begin{array}{l}\text { Water } \\
\text { productivity, US } \\
\text { thsd dollars }\end{array}$ & $\begin{array}{l}\text { Waste } \\
\text { productivity, US } \\
\text { thsd dollars }\end{array}$ & $\begin{array}{c}\text { Total, US thsd } \\
\text { dollars }\end{array}$ \\
\hline \multicolumn{7}{|l|}{ Leaders } \\
\hline France & 9 & 761.38 & 15678.47 & 811.04 & 29388862.67 & 29406113.57 \\
\hline USA & 20 & 231.07 & 3818.22 & 8611.24 & 1595697.47 & 1608358.01 \\
\hline Brazil & 2 & 234.77 & 1490.65 & 71.19 & 343444.94 & 345241.57 \\
\hline India & 1 & 356.10 & 161.64 & 17.57 & 326956.07 & 327170.90 \\
\hline Germany & 7 & 274.52 & 2437.69 & 267.44 & 229263.72 & 232243.38 \\
\hline Norway & 2 & 9096.11 & 48913.50 & 603.30 & 169069.09 & 227682.01 \\
\hline Ireland & 2 & 352.28 & 210.06 & 226.33 & 104018.69 & 104490.31 \\
\hline South Korea & 2 & 104.85 & 574.49 & 151.22 & 115246.79 & 116077.37 \\
\hline \multicolumn{7}{|c|}{ Middle peasants } \\
\hline Italy & 1 & 24.35 & 334.17 & 15.55 & 83655.58 & 84029.65 \\
\hline Singapore & 3 & 8.22 & 70.80 & 123.21 & 76033.66 & 76235.91 \\
\hline Japan & 5 & 17.01 & 274.20 & 13.45 & 68785.47 & 69090.14 \\
\hline Great Britain & 5 & 81.62 & 676.67 & 37.07 & 27580.96 & 28376.35 \\
\hline Spain & 3 & 20.68 & 185.00 & 24.83 & 20217.52 & 20448.04 \\
\hline Canada & 13 & 387.45 & 5994.28 & 70.86 & 19442.11 & 25894.71 \\
\hline China & 2 & 143.12 & 297.69 & 39.82 & 7544.83 & 8025.47 \\
\hline Denmark & 5 & 23.80 & 323.74 & 53.86 & 7370.30 & 7771.72 \\
\hline Finland & 5 & 23.80 & 323.74 & 53.86 & 7370.30 & 7771.72 \\
\hline
\end{tabular}




\begin{tabular}{|c|c|c|c|c|c|c|}
\hline Country & $\begin{array}{l}\text { Number of } \\
\text { companies }\end{array}$ & $\begin{array}{c}\text { Energy } \\
\text { productivity, US } \\
\text { thsd dollars }\end{array}$ & $\begin{array}{l}\text { Carbon } \\
\text { productivity, US } \\
\text { thsd dollars }\end{array}$ & $\begin{array}{l}\text { Water } \\
\text { productivity, US } \\
\text { thsd dollars }\end{array}$ & $\begin{array}{l}\text { Waste } \\
\text { productivity, US } \\
\text { thsd dollars }\end{array}$ & $\begin{array}{l}\text { Total, US thsd } \\
\text { dollars }\end{array}$ \\
\hline Australia & 2 & 34.26 & 221.56 & 55.28 & 6739.10 & 7050.20 \\
\hline Netherlands & 3 & 107.06 & 1536.30 & 319.76 & 5493.13 & 7456.26 \\
\hline Sweden & 2 & 22.06 & 155.00 & 19.05 & 4271.62 & 4467.74 \\
\hline Taiwan & 1 & 1.57 & 8.67 & 1,18 & 3566.10 & 3577.54 \\
\hline \multicolumn{7}{|l|}{ Outsiders } \\
\hline Switzerland & 1 & 333.6 & 28.03 & 3.33 & 582.87 & 617.57 \\
\hline Hong Kong & 1 & 0.905 & 8.76 & 0.25 & 96.08 & 106.01 \\
\hline Turkey & 1 & 16.54 & 176.90 & 11.65 & 359.33 & 564.43 \\
\hline Austria & 1 & 0.44 & 3.88 & 0.035 & & 4.37 \\
\hline
\end{tabular}

Calculated by the authors according to CK (2021)

Singapore with 76235.91 thsd US dollars, and Japan with 69090.14 thsd US dollars. Only 4 of 25 belong to the outsiders: Switzerland, Hong Kong, Turkey and Austria, with the total environmental funding from sustainable business conduct of 1292.38 thsd US dollars, or $0.004 \%$ of the total leaders' and $0.37 \%$ of middle peasants' funding.

The costs of the environmental block indicate not only the environmentally-oriented activities of companies, but also the fight against the effects of pollution caused by their activities. In the fight against waste, the leaders of the rating direct their efforts to regenerative agriculture.

Fulfilment of their climate obligations and carbon footprint is carried out mainly by companies that use renewable energy sources in their activities. At the same time, only Germany turns out to be the country of Central and Eastern Europe that make its business sustainable. Unfortunately, the post-Soviet countries, to which Ukraine belongs, will not show the capacity for sustainable business.

Areas of sustainable business are intensively developing in economically developed countries. The following goals are priority areas for the development of Ukrainian sustainable business: quality education, decent work and economic growth, good health and well-being. However, it must be noted that a large number of Ukrainian companies are focused on the sustainability of corporate governance and do not always publish their indicators regarding sustainable business.
Meanwhile, monopolists of the Ukrainian market have already passed to international requirements for sustainable business and disseminate information about the goals of sustainable development, which are embedded in the strategies of their development. The largest of them are those that have included the environmental block, namely Nestlé in Ukraine, Carlsberg Ukraine PJSC and Ukrgasbank.

Focusing on the data of the report "The contribution of Ukrainian business to the implementation of Ukraine's Sustainable Development Goals 2016-2020" (CSR Ukraine, 2020), the sustainable development benchmarks of Nestlé in Ukraine are:

quality of life and healthy future: helping children to lead a healthy lifestyle (Nestlé, 2020);

social and economic sustainability: improving the lives of communities, farms directly involved in production;

protection and rational use of natural resources in the production of their products: aiming for zero impact on the environment. Together Towards ZERO program (Nestlé, 2020) reflects a vision for a better future in the period of severe challenges, such as climate change, water scarcity and threats to public health. In order to achieve the ZERO program goal by 2050 , Nestlé is implementing changes in the value chain and operations, e.g., working with farmers to switch to regenerative food ingredients, including the products we produce, and increasing the amount of carbon neutral brands to enable consumers to 
contribute to the fight against climate change, thus compensating for emissions with soil and forest restoration projects. The strategy provides:

Zero carbon footprint: $0 \%$ of carbon dioxide emissions in breweries by $2030,100 \%$ of electricity use from renewable sources in breweries by 2022, 30\% reduction of carbon footprint of finished products by 2030;

Zero water losses: 50\% reduction in water use in breweries; development of cooperation for protection of general water resources in areas with a high risk of water scarcity;

\section{Zero irresponsible beer consumption;}

Zero accidents.

Ukrgasbank has invested 7 goals in the concept of its development to achieve the level of sustainable business by implementing the Environmental Management System (Ukrgasbank, 2021):

"green" financing;

reduction of the negative impact of bank's activities;

assessment and monitoring of environmental and social risks of borrowers;

implementation of practices that ensure the prevention of corruption, bribery and money laundering, fairness and transparency in relations with stakeholders;

economic development, i.e., supporting economic development of Ukraine through supporting strategic development areas of the economy;

development of staff working conditions and employer values: the bank is trying to create comfortable working conditions that include gender equality, clear and understandable hierarchy and transparent communication;

internal environmental measures such as reduction of internal resource consumption on carbon dioxide emissions gas.

The analyzed data show that sustainable business in Ukraine has just been established. In foreign practice (impact assessment B, 2021), there are 15,000 companies that are engaged in sustainable business; meanwhile, in Ukraine, there are only 3 such companies as of the end of 2020: Nestlé's environmental sustainability policy (Nestle, 2020); Carlsberg Sustainability Report (Carlsberg Ukraine, 2019); and Ukrgasbank is among the leaders in the sustainable development of Ukrainian business (Ukrgasbank, 2021). Only monopolists have invested in their strategic goals for all three blocks of environmental impact, social policy, and quality assessment of corporate governance for sustainable business development. Regarding the economic situation in Ukraine now, only monopolist companies can achieve Sustainable Goals without financial risks for the business.

In consideration of the foregoing, it is worth considering promising regions for the formation of sustainable business there, not only for monopolists, but also for small businesses under economic, social and environmental criteria by ranking in accordance with the Sustainable Development Goals.

According to the ecological criterion, we distinguish the following indicators that reflect the qualitative and negative characteristics for the formation of competitive advantages of sustainable business: waste generation, total amount of waste accumulation, emissions of pollutants into the atmosphere, carbon dioxide emissions, water losses, water pollution, disturbed, used and reclaimed lands, which negatively affect the formation of regional reserves. The positive factors include nature protected areas, Nature Reserve Fund of Ukraine (NRF) territories (MENRU, 2021), water protection zones and coastal protection belts of water bodies, presence of subsoil, presence of seas, rivers and lakes, as well as the cost of environmental protection. The economic criterion includes indicators of available income per person, GRP income per person, sold goods and services in the field of inclusive economy of impressions, financial results of enterprises before tax, capital investments, rent for the use of natural resources. The social criterion includes qualitative characteristics such as drinking water supply, public employment, household expenditures, and negative indicators such as the number of viral infections and respiratory diseases, the rate of impoverishment.

According to research and expert opinions of scientists (OECD, 2018), indicators were selected for ranking. In terms of the requirements of sustainable development (Lagarde, 2014), increasing and investing 
households in education and health care are directly dependent on access to decent work and finance for all segments of the population.

Calculations were done by statistical methods for determination of closeness of the relationship between these assessment criteria in order to establish the basic parameters of the process of sustainable business conduct in terms of regions of Ukraine. The distribution of the regions according to the selected criteria was carried out by the method of ranking based on the rationing of individual indicators (according to formulae 1,2) in the regional context according to the specified criteria.

If the growth of individual indicators leads to an increase in individual assessments, the rationing of indicators is carried out according to formula 1, otherwise according to formula 2.

$$
Z_{i}=\frac{x_{i}-x_{\min }}{x_{\max }-x_{\min }},
$$

$$
Z_{i}=\frac{x_{\max }-x_{i}}{x_{\max }-x_{\min }},
$$

where $Z_{i}$ is the normalized value of individual indicators $(0 \leq \leq 1) ; x_{\max }, x_{\min }, x_{i}$ is a maximum, minimum, $i$-th value of the individual indicator.

Accordingly, the higher the , the more the region is suitable for sustainable business development. A summary information of indicators according to the selected criteria is given in Table 2 .

\begin{tabular}{|c|c|c|c|c|}
\hline Region & ¿Zi ecological criterion & $\Sigma Z i$ economic criterion & $\sum Z$ Zi social criterion & $\sum$ Zi general indicator \\
\hline Vinnytsia & 7.82 & 4.04 & 3.17 & 15.04 \\
\hline Volyn & 8.72 & 1.78 & 2.24 & 12.74 \\
\hline Dnepropetrovsk & 6.28 & 4.88 & 4.02 & 15.19 \\
\hline Donetsk & 4.75 & 1.98 & 2.76 & 9.49 \\
\hline Zhytomyr & 7.45 & 2.36 & 2.55 & 12.37 \\
\hline Transcarpathian & 9.37 & 1.80 & 3.61 & 14.78 \\
\hline Zaporozhye & 9.77 & 2.95 & 3.70 & 16.43 \\
\hline Ivano-Frankivsk & 7.07 & 2.27 & 4.30 & 13.64 \\
\hline Kyiv & 9.61 & 4.98 & 2.84 & 17.44 \\
\hline Kirovograd & 7.07 & 2.35 & 2.96 & 12.40 \\
\hline Luhansk & 7.24 & 1.29 & 2.55 & 11.09 \\
\hline Lviv & 7.72 & 3.98 & 5.00 & 16.71 \\
\hline Mykolayivska & 8.22 & 2.58 & 3.86 & 14.67 \\
\hline Odessa & 8.10 & 4.55 & 3.40 & 16.06 \\
\hline Poltava & 8.78 & 3.86 & 3.47 & 16.11 \\
\hline Rivne & 8.87 & 2.12 & 2.50 & 13.51 \\
\hline Sumy & 7.84 & 2.41 & 1.87 & 12.13 \\
\hline Ternopil & 7.92 & 1.85 & 3.45 & 13.23 \\
\hline Kharkiv & 6.66 & 4.07 & 4.91 & 15.65 \\
\hline Kherson & 7.83 & 3.11 & 2.474 & 13.42 \\
\hline Khmelnytsky & 8.41 & 3.29 & 2.39 & 14.10 \\
\hline Cherkasy & 7.07 & 2.35 & 2.13 & 11.56 \\
\hline Chernivtsi & 7.43 & 1.80 & 3.67 & 12.91 \\
\hline Chernihiv & 7.90 & 2.48 & 3.54 & 13.93 \\
\hline
\end{tabular}

Table 2. Summary table of indicators z_i by environmental, economic and social criteria 
Further ranking of regions can be carried out by a 3-level gradation: optimal, satisfactory, and negative level of sustainable business conduct (Table 3 ).

The obtained results show that there are only 8 regions suitable for sustainable business conduct: Vinnytsia,
Zaporizhzhia, Dnipropetrovsk, Kyiv, Lviv, Odesa, Poltava, and Kharkiv. The development of sustainable business in Ukraine just begins its formation based on the best international practices, but still holds the position of responsible business.

Table 3. Gradation levels according to ecological, economic, social and generalizing criteria

\begin{tabular}{l|c|c|c|c}
\hline \multicolumn{1}{|c|}{ Levels } & Ecological criteria & Economic criteria & Social criteria & Generalizing criteria \\
\hline Optimal & $8.10-9.77$ & $3.75-4.98$ & $3.95-5.00$ & $14.79-17.44$ \\
\hline Satisfactory & $6.42-8.10$ & $2.52-3.75$ & $2.91-3.95$ & $12.14-14.79$ \\
\hline Negative & $4.74-6.42$ & $1.29-2.52$ & $1.87-2.91$ & $9.49-12.14$ \\
\hline
\end{tabular}

At the same time, the analysis of the suitability of regions for the organization of sustainable business is reduced to 5 key dominants of the formation of mechanisms of state strategic investment and innovation policy of the system of sustainable development support, namely:

public investment and expenditures (cost optimization in regions that stimulate national economies);

use of environmental taxes and other market instruments that minimize external impact on the environment and compensate for market weakness;

reforming of environmentally harmful budget subsidies (limitation of state support for industries that deplete natural capital);

improvement of legislative regulation;

development of international cooperation in the field of ecology and resource consumption.

\section{Conclusions}

Within the framework of the research, a methodological approach was proposed to assess the sustainability of business conduct, which provides a procedure and a stepwise assessment of compliance of modern business with the criteria and Sustainable Development Goals. The research proves that the Sustainable Development Goals are reflected in foreign practices of sustainable business, which is confirmed by contributions to overcoming the environment degradation impact in terms of energy productivity, carbon productivity, water productivity, waste productivity by 25 countries in the amount of 327188 million US dollars. At the same time, almost $90 \%$ is invested in waste productivity. The leaders in funding are France, the United States, Brazil, India, Germany, Norway, Ireland and South Korea with a contribution to the environment protection in the amount of 323673 million US dollars, which is more than $92 \%$ of the total contribution by countries.

Previously, the focus on sustainability mostly included the environmental component and the development of "green" business. Over time, the inclusion of the social factor has proved that the company's competitive advantages depend more on the environment for employees. Having combined such goals and the desire to make a profit required taking into account the Sustainable Development Goals in the activities of companies. A review of international trends to the sustainable business conduct proves that sustainability depends not only on the passage to cleaner production and consumption, but to a greater extent on the desire of companies to implement business policies for nature. This is evidenced by the fact that already 8080 foreign companies are considered to be sustainable. In Ukrainian practice, there are only 3 such companies that fully meet the requirements of sustainable business in their business activities. These are mainly monopolists of the Ukrainian business market. The focus on conducting sustainable business in Ukraine is gaining momentum and many 
companies are already investing their activities in the goals of sustainable business. Therefore, it was worth considering the suitability of the regions of Ukraine for the implementation of practices of sustainable business conduct. According to the ecological criterion, the most stable are Zaporizhzhia, Zakarpattia and Kyiv regions, with an indicator of more than 9.2 points of 10. According to the economic criterion, which did not exceed the mark of 5, Kyiv (4.99), Odesa (4.55) and Dnipropetrovsk (4.88) regions are more suitable. Lviv, Ivano-Frankivsk and Dnipropetrovsk regions meet the requirements of the social criterion of compliance with sustainable business conduct in points ranging 4.02-5.02. The calculations show that only 8 of 24 regions are suitable for the sustainable business development according to 3 criteria: environmental, social, and economic. Based on international recommendations for sustainable development, in Ukraine, first of all, it is necessary to regulate at the legislative level the compliance with the requirements of environmental laws, the provision of subsidies for innovative and sustainable business models. Achievement of transformations is possible under the conditions of spreading the practice of the provision to companies

\section{References}

Andryeyeva N., Tiutiunnyk H, Burkinsky B., Khumarova N., Kupinets L. (2020). Methodological approach of investment and innovation regional environmental policy using the Smart Specialization and Quintuple helix models. Ekonomica i Środowisko 74(3), 28 https://doi.org/10.34659/2020/3/24

ASQ (American Society for Quality) (2019). What is ISO 26000 - Guidance on Social Responsibility? Available at: https://asq. org/quality-resources/iso-26000\#: :text=ISO\%2026000\%20 is $\% 20$ defined $\% 20$ as, other $\% 20$ stakeholders\%3B\%20and $\% 20$ environmental\%20impact./ (accessed 18 March 2021)

B Impact Assessment (2021) Case Studies. Available at: https:/ / bimpactassessment.net/case-studies (accessed 15 April 2021)

B4SI (Business for Societal Impact) (2020). The Global Standard in Measuring and Managing a Company's Social Impact. Available at: https://b4si.net/framework/community-investment/ (accessed 18 March 2021).

Bansal P., DesJardine MR. (2014). Business sustainability: It is about time. Strategic Organization. 12(1), 70-78. https://doi. org/10.1177/1476127013520265 of transparent information about the environmentally-oriented activities, publishing of the brightest business decisions regarding the termination of degradation processes in their practice, or alternative activities aimed at overcoming imbalances in another sector of the economy through capital investment from profit earned.

Prospects for further development and research will lie in a methodological justification of opportunities and threats to the implementation of sustainable business, taking into account regional resource characteristics and existing state programs of socio-economic and environmental development.

\section{Acknowledgements}

The article was written in connection with the Research work "Dominants of investment and innovation policy of nature management of the national economy 'budget program' Support for the development of priority areas of research" (Code of the budget program 6541230).

B-Corp (Certified B Corporations) (2021). A Global Community of Leaders. Available at https://sustainabledevelopment.un.org/partnership/?p=12273 (accessed 18 May 2021)

Bobkova A., Andryeyeva N., Verbivsk L., Kozlovtseva V., Velychko V. (2020) Organizational and Economic Tools for the Development of Environmental Entrepreneurship. International Journal of Management (IJM). 11(6), 334-350. Available at: http://www. iaeme.com/MasterAdmin/Journal_uploads/IJM/VOLUME_11_ ISSUE_6/IJM_11_06_029.pdf (accessed 11 March 2021)

Carlsberg Ukraine (2019). Carlsberg Sustainable Development Report. Available at: https://carlsbergukraine.com/en/sustainability/sustainability-at-carlsberg/ (accessed 11 March 2021)

CK (Corporate Knights) (2021). Global 100. Overview of Corporate Knights Rating Methodology Available at: https://www.corporateknights.com/wp-content/uploads/2018/10/2019-Global-100_Methodology-Final.pdf?v=20181205 (accessed 30 April 2021)

COE (Communication on Engagement) (2021). Stichting Global Reporting Initiative. Available at: https://www.globalreporting. 
org/about-gri/mission-history/gri-s-own-reports/. (accessed 25 March 2021)

Costanza R., Groot R., Braat L., Fioramonti L., et al, (2017). Twenty years of ecosystem services: How far have we come and how far do we still need to go?. Ecosystem Services 28(A), 1-16. https://doi.org/10.1016/j.ecoser.2017.09.008

CSA (Canadian Standards Association) (2013). CSA Group. Available at: https://webstore.ansi.org/products/new-products (accessed 30 March 2021)

CSR Ukraine (Create Sustainable Results Ukraine) (2020). The contribution of Ukrainian business to the implementation of Ukraine's Sustainable Development Goals 2016-2020. Available at: https://csr-ukraine.org/wp-content/uploads/2020/12/ Vpliv-biznesu-na-CSR.pdf (accessed 17 April 2021)

Deloitte (2017). 2030 Purpose: Good business and a better future. Available at: https://www2.deloitte.com/global/en/pages/about-deloitte/articles/purpose-2030-good-business-better-future.html. (accessed 17 April 2021)

DSTU (State Standards of Ukraine) (2018). Information support in the field of technical regulation of SE "Ukrmetrteststandard". Available at: http://csm.kiev.ua/nd/nd.php?b=1 (accessed 11 March 2021)

Duckett M. K. (2020). The business of nature. National Geographic. Available at: https://www.nationalgeographic.com/ science/article/partner-content-business-of-nature (accessed 30 March 2021).

Elkington J. (2004). The Triple Bottom Line: Does it all add up? Available at: https://www.johnelkington.com/archive/TBL-elkington-chapter.pdf (accessed 18 April 2021).

EU (European Union) (2021). Taxonomy Solution. Available at: https://www.sustainalytics.com/investor-solutions/esg-research/eu-sustainable-finance-action-plan-solutions/eu-taxonomy-solution. (accessed 25 May 2021)

Geissdoerfer M., Vladimirova D., Evans S. (2018). Sustainable business model innovation: A review. Journal of Cleaner Production, 198, 401-416. https://doi.org/10.1016/j.jclepro.2018.06.240

Gómez-Bezares F., Przychodzen, W., Przychodzen, J. (2016). Corporate sustainability and shareholder wealth- Evidence from British Companies and Lessons from the Crisis. Sustainability 8(3), 276. https://doi.org/10.3390/su8030276

Groot R., Brander L., Costanza R., Bernard F., et al., (2012) Global estimates of the value of ecosystems and their services in monetary units. Ecosystem Services, 1(1), 50-61. https://doi. org/10.1016/j.ecoser.2012.07.005

GSB (Government service for business) (2020). Sweden Sustainable business. Available at: https://www.verksamt.se/web/ international/starting/sustainability/ (accessed 30 March 2021)
Harold L., Murray T. (1975). The Delphi Method: Techniques and Applications. Available at https://doi.org/10.2307/3150755. (accessed 12 April 2021)

Impact Garden (2020). Responsible Business. Available at: https://impactgarden.org/responsible-business/ (accessed 30 March 2021)

ISO (International Organization for Standardization) (2009). IEC 31010:2019 Risk management - Risk assessment techniques. Available at: https://www.iso.org/standard/51073.html (accessed 18 March 2021)

ISO (International Organization for Standardization) (2011). 14000 Family Environmental Management. Available at https://www.iso.org/iso-14001-environmental-management. html (accessed 18 March 2021).

ISO (International Organization for Standardization) (2011). ISO 14000 Environmental Management. Available at: https://www. iso.org/ru/iso-14001-environmental-management.html (accessed 18 March 2021)

Jonkute G. (2015). The Consumers' Approach to Sustainable Consumption and Production: a Case Study in Lithuania. Environmental Research, Engineering and Management 71(4), 2846. https://doi.org/10.5755/j01.erem.71.4.13642

Jounkute G. (2015). Assessment of Overall SCP State of Company: Results of Application of New Integrated Sustainability Index ISCP in 2 Enterprises. Environmental Research, Engineering and Management, 71(2), 42-53. https://doi.org/10.5755/ j01.erem.71.2.12332

Khotomlyansky A., Znahurenko P. (2005). Methods of ranking the portfolio of investment projects of the enterprise. Bulletin of the Azov State Technical University. Series: Technical Sciences 15(1) Available at: https://cyberleninka.ru/article/n/metody-ranzhirovaniya-portfelya-investitsionnyh-proektov-predpriyatiya (accessed 17 April 2021).

Kostetska K., Khumarova N., Umanska Y., Shmygol N., Koval, V. (2020). Institutional qualities of inclusive environmental management in sustainable economic development. Management Systems in Production Engineering, 28 (2), 15-22. https://doi. org/10.2478/mspe-2020-0003

Kostetska K., Laurinaitis M., Savenko I., Sedikova I., Sylenko S. (2020). Mining management based on inclusive economic approach E3S Web Conf. 201(01009). https://doi.org/10.1051/ e3sconf/202020101009

Label R (Label reputation, risk, responsibility) (2018). An industry-leading innovative approach to ESG risk assessment and due diligence. Available at https://www.label-r.com/ (accessed 18 March 2021)

Lagarde, C. (2014). Promoting Responsible Energy Pricing. International Monetary Fund. Available at: https://www.imf.org/ 
en/News/Articles/2015/09/28/04/53/sp073114 (accessed 7 April 2021).

Lassaad Ben M., Khmaoussi H. (2012). Communication on Corporate Social Responsibility and Sustainable Development in France. Environmental Research, Engineering and Management 61(3), 73-79. https://doi.org/10.5755/j01.erem.61.3.1393

LCSA (Life cycle sustainability assessment) (2020). Life Cycle Initiative. Available at: https://www.lifecycleinitiative.org/starting-life-cycle-thinking/life-cycle-approaches/life-cycle-sustainability-assessment/ (accessed 11 March 2021).

MENRU (Ministry of Ecology and Natural Resources of Ukraine) (2021). Nature Reserve Fund of Ukraine. Available at: http://pzf. menr.gov.ua/ (accessed 11 March 2021).

Mikušová M. (2017). To be or not to be a business responsible for sustainable development? Survey from small Czech businesses. Economic Research-Ekonomska Istraživanja 30(1), 1318-1338. https://doi.org/10.1080/1331677X.2017.1355257

$\mathrm{MSCl}$ (Morgan Stanley Capital International) (2019). What is an ESG Rating? Available at: https://www.msci.com/research/ esg-research (accessed 21 May 2021)

Nestlé (2020). How Nestlé is improving children's health. Helping children live healthier lives. Available at: https://www.nestle.com/csv/global-initiatives/healthier-kids

Nestlé (2020). The Nestlé Policy on Environmental Sustainability. Policy Mandatory. Available at: https://www.nestle.ua/ randd/environmental-sustainability (accessed 11 March 2021)

Nestlé (2020). Together Towards ZERO's program. Available at: https://www.nestle.com/csv/global-initiatives/zero-environmental-impact/climate-change-net-zero-roadmap

OECD (Organization for Economic Co-operation and Development) (2018). Tax policies for inclusive growth in a changing world OECD report to G-20 Finance Ministers and Central Bank Governors. Available at: http://www.oecd.org/g20/Tax-policies-for-inclusive-growth-in-a-changing-world-OECD.pdf (accessed 17 April 2021)

OECD (Organization for Economic Co-operation and Development) (2011). Guidelines for Multi-Nation Enterprises. Recommendations for responsible management business in a global context. Available at: https://business.diia.gov.ua/uploads/1/7718-kerivni_princii_oesr_dla_bagatonacional_nih_ pidpriemstv.pdf (accessed 30 March 2021).

Painter-Morland M., Bos, R. (2016). Should environmental concern 'pay off? A Heideggerian perspective. Organization Studies 37(4), 547-567. https://doi.org/10.1177/0170840615604502

Raed El-K., Mohamad Ali M. (2020). The mediating impact of sustainability on the relationship between agility and operational performance. Operations Research Perspectives 7(100171), 1-17. https://doi.org/10.1016/j.orp.2020.100171
Rahdari A., Sepasi S. Moradi M. (2016). Achieving sustainability through Schumpeterian social entrepreneurship: The role of social enterprises. Journal of Cleaner Production. 137, 347-360. https://doi.org/10.1016/j.jclepro.2016.06.159

RSU (Regional Statistics of Ukraine) (2021). Comprehensive regional statistics. Available at: http://www.ukrstat.gov.ua/druk/ publicat/kat_u/publ2_u.htm (accessed 17 May 2021)

S\&P Global (Standard \& Poor's Financial Services) (1999). The Dow Jones Sustainability Index. Available at: https://www.spglobal.com/spdji/en/indices/equity/dow-jones-global-index/ (accessed 11 March 2021)

SAERG (Swedish Agency for Economic and Regional Growth) (2021). What is sustainable business. Available at: https:// www.verksamt.se/web/international/starting/sustainability/ (accessed 15 March 2021)

SDG Compass (Sustainable Development Goals Compass) (2015). The guide for business action on the SDGs. Available at: https:// sdgcompass.org/wp-content/uploads/2015/12/019104_SDG_ Compass_Guide_2015.pdf (accessed 18 March 2021)

Shevchenko H., Petrushenko M., Burkynskyi B., Khumarova N. (2020). SDGs and the ability to manage change within the European green deal: The case of Ukraine. Problems and Perspectives in Management, 19(1), 53-67. https://doi.org/10.21511/ ppm.19(1).2021.05

Shevchenko H., Petrushenko M., Burkynskyi B., Khumarova N., Opanasiuk Y. (2020). Management of wellness and recreation in urban agglomerations. Problems and Perspectives in Management 18(1), 231-241. https://doi.org/10.21511/ ppm.18(1).2020.20

SSSU (State Statistics Service of Ukraine) (2021) Number of employees of business entities. Available at: https://ukrstat. org/uk/operativ/operativ2012/fin/roz_p.htm (accessed 11 March 2021)

SSSU (State Statistics Service of Ukraine) (2021). Capital investments by regions. Available at: https://ukrstat.org/uk/operativ/operativ2021/ibd/kin/kin_reg/arh_kin_reg2021_u.htm (accessed 11 March 2021)

SSSU (State Statistics Service of Ukraine) (2021). Economic and Environmental Statistics. Available at: http://www.ukrstat.gov. ua (accessed 30 April 2021)

SSSU (State Statistics Service of Ukraine) (2021). Gross regional product. Available at: https://ukrstat.org/uk/operativ/operativ2021/vvp/kvartal_new/vrp/arh_vrp_u.html (accessed 11 March 2021)

SSSU (State Statistics Service of Ukraine) (2021). Personnel costs of enterprises. Available at: https://ukrstat.org/uk/operativ/operativ2013/fin/kp_reg/kp_reg_u/arh_vpp_reg_u.htm (accessed 11 March 2021) 
Stasiskiene P., Meiliene E., Ciutiene R., \& Petkeviciene J. (2021). Innovation Ecosystem for Sustainable Business Model Development: Practical Insights. Environmental Research, Engineering and Management, 77(2), 63-70. https://doi.org/10.5755/ j01.erem.77.2.29056

Sustainable Ukraine (2020). Rating Sustainable Ukraine. Available at: https://sustainableukraine.com/ua/index.html\#block-8 (accessed 17 April 2021)

The B Impact Assessment (2021). The most credible tool a company can use to measure its impact on its workers, community, environment, and customers. Available at: https://bimpactassessment.net/?_ga=2.82975508.367175968.16213455171525410743.1618250796 (accessed 17 April 2021)

The Dow Jones Sustainability Indices (1999). Your Single Source of Essential Sustainability Intelligence. Available at: https://www.spglobal.com/esg/performance/indices/djsi-index-family (accessed 30 March 2021)

Ukrgazbank (2021). Ukrgazbank among the leaders of sustainable development of Ukrainian business. Available at: http:// www.ukrgasbank.com/press_center/news/12798-ukrgazbank_sredi_liderov_ustoyichivogo_razvitiya_ukrainskogo_biznesa_221 (accessed 11 March 2021)

UN (United Nations) (2015). Transforming our world: the 2030 Agenda for Sustainable Development. A/RES/70/1. Available at: https://sdgs.un.org/2030agenda (accessed 15 May 2021)

UN (United Nations) (2021). Nature's Dangerous Decline ‘Unprecedented; Species Extinction Rates “Accelerating”. Available at: https://www.un.org/sustainabledevelopment/ blog/2019/05/nature-decline-unprecedented-report/ (accessed 18 May 2021)

UN Global Compact (United Nation Global Compact) (2021). UN Global Compact Strategy 2021-2023. Policy Document. Available at: https://unglobalcompact.org/library/5869 (accessed 15 April 2021)

Upcounsel (2021). Green Business Definition: Everything You Need to Know. Available at: https://www.upcounsel.com/ green-business-definition (accessed 30 March 2021)

US EPA (United States Environmental Protection Agency) (2021). Learn About Environmental Management Systems. Available at: https://www.epa.gov/ems/learn-about-environmental-management-systems\#what-is-an-EMS

VRU (Verkhovna Rada of Ukraine) (2020). Concept implementation of state policy in the field of promoting the development of socially responsible business in Ukraine until 2030. Available at: https://zakon.rada.gov.ua/laws/show/66-2020-\%D1\%80\#n8 (accessed 18 March 2021)

World Business Council for Sustainable Development (2020). Sustainble Development Goals. Available at https://sustainabledevelopment.un.org/partnership/? $\mathrm{p}=12273$ (accessed 18 April 2021)

Zahid M., Haseeb J., Rahman U., Mata M., Shah S., Mata P. (2021). The Interconnection between Decent Workplace and Firm Financial Performance thrugh the Mediation of Environmental Sustainability: Lessons from an Emerging Economy. Sustainability 13(8) https://doi.org/10.3390/su13084570 https://doi.org/10.3390/su13084570 